\title{
Identity of Microfilariae Circulating in Dogs from Western and South-Western Romania in the Last Decade
}

\author{
Simona Giubega ${ }^{1}$, Mirela Imre ${ }^{1}$, Marius Stelian Ilie ${ }^{1, * \mathbb{D}}$, Kálmán Imre ${ }^{2} \mathbb{D}$, Iasmina Luca ${ }^{1} \mathbb{D}$, Tiana Florea ${ }^{1}$, \\ Gheorghe Dărăbuș ${ }^{1}$ and Sorin Morariu ${ }^{1}$
}

1 Department of Parasitology and Dermatology, Banat's University of Agricultural Sciences and Veterinary Medicine "King Michael I of Romania" from Timisoara, Calea Aradului 119, 300645 Timisoara, Romania; simonagiubega@gmail.com (S.G.); mirela.imre@gmail.com (M.I.); iasminaluca0@gmail.com (I.L.); suici.tijana@gmail.com (T.F.); gheorghe.darabus@fmvt.ro (G.D.); sorin.morariu@fmvt.ro (S.M.)

2 Department of Animal Production and Veterinary Public Health, Banat's University of Agricultural Sciences and Veterinary Medicine "King Michael I of Romania" from Timisoara, Calea Aradului 119, 300645 Timisoara, Romania; kalmanimre@usab-tm.ro

* Correspondence: marius.ilie@fmvt.ro; Tel.: +40-256-277-190

check for updates

Citation: Giubega, S.; Imre, M.; Ilie, M.S.; Imre, K.; Luca, I.; Florea, T.; Dărăbuș, G.; Morariu, S. Identity of Microfilariae Circulating in Dogs from Western and South-Western Romania in the Last Decade. Pathogens 2021, 10, 1400. https:// doi.org/10.3390/pathogens10111400

Academic Editors: Angela Di Cesare, Donato Traversa and Simone Morelli

Received: 30 September 2021

Accepted: 26 October 2021

Published: 29 October 202

Publisher's Note: MDPI stays neutral with regard to jurisdictional claims in published maps and institutional affiliations.

Copyright: (c) 2021 by the authors. Licensee MDPI, Basel, Switzerland. This article is an open access article distributed under the terms and conditions of the Creative Commons Attribution (CC BY) license (https:// creativecommons.org/licenses/by/ $4.0 /)$.

\begin{abstract}
Dirofilaria infections in dogs are recognized as widespread mosquito-borne diseases with zoonotic potential, that are caused by the filarioid nematode (Onchocercidae) species Dirofilaria immitis and Dirofilaria repens. The long-term survey conducted in western and south-western Romania was undertaken in order to provide valuable data on the occurrence of Dirofilaria infections in dogs. Blood samples from 1088 dogs, originating from 73 localities of 11 western and south-western counties in Romania, were collected and examined using the modified Knott test. Subsequently, all of the microscopically positive samples were subjected to molecular analysis for confirmation. Altogether, the data obtained showed the percentage of dogs with circulating microfilariae to be $21.42 \%(233 / 1088)$ of dogs tested in the investigated region. The identified species, in cases of monoinfections, were D. immitis, D. repens, and Acanthocheilonema reconditum in 106 (9.74\%) samples, 102 (9.38\%) samples, and $1(0.09 \%)$ sample, respectively. Twenty-four (2.21\%) samples were simultaneously positive for $D$. immitis and $D$. repens. There was no association $(p>0.05)$ between infection status and breed; however, sex and lifestyle were positively associated $(p<0.05)$ with the percentage of dogs with circulating microfilariae and might be regarded as risk factors for infection. The results of the present investigation indicate potential zoonotic risks for humans living in the screened area and support the imperative to increase awareness among both veterinarians and physicians, regarding the continuous spread of these zoonotic filariae.
\end{abstract}

Keywords: Dirofilaria; Acanthocheilonema; dogs; dirofilariosis; Romania

\section{Introduction}

Dirofilaria infections in dogs are widespread mosquito-borne diseases caused by filarioid nematodes (Onchocercidae) with a zoonotic potential-namely, Dirofilaria immitis and Dirofilaria repens [1,2].

Dirofilaria immitis and Dirofilaria repens are two of the most well-known vector-borne helminths, both exerting a severe influence on veterinary care and public health, due to the emergence of canine cardiopulmonary and subcutaneous dirofilariosis in both dogs and humans [3].

While some Dirofilaria-infected dogs do not show any clinical signs of disease, others may exhibit clinical signs of variable intensity, depending on the implicated filarial species. Dirofilaria immitis, the etiological entity causing canine heartworm disease (HD) is commonly found in pulmonary arteries. Worms can also be found in the right cardiac ventricle, the right atrium, and (in worst case scenarios/in advanced stages of the disease) in the vena cava. The disease has a severe impact on veterinary medicine due to its clinical 
signs which include, among others (depending on the evolution), coughing, dyspnoea, weakness, and death. Dirofilaria repens, an agent that generally causes subclinical infections, is responsible for subcutaneous dirofilariosis in dogs and it is frequently linked with the presence of adults in subcutaneous tissues, representing the main cause of human dirofilariosis. The clinical signs of this infection in dogs include pruritus, localized alopecia, or cutaneous ulceration [3-9].

The diagnosis of canine heartworm disease is based on the corroboration of results from detailed clinical examinations with a combination of different diagnostic methods, including revealing the presence of blood microfilariae, radiographic examinations, echocardiography, rapid antigen tests, ELISA, or polymerase chain reaction (PCR) [10-12].

The detection and identification of circulating microfilariae, the morphological and molecular identification of adult parasites, and the cytological and histological analysis of nodules can all be used to make a $D$. repens diagnosis [7].

Canine dirofilariosis is an endemic disease in many European countries [13], including Romania, where the prevalence of $D$. immitis has been reported to range between $0 \%$ and $60 \%$, depending on the surveyed area and the diagnostic tool used [14-19]. Recent studies performed on Romanian territory offer information regarding the presence of this parasite in other regions found at considerable distances from the areas included in the present study. The results of our study aim to complete the epidemiological map of the Dirofilaria-circulating microfilariae that are spread among the canine population. The goal of our study was to provide updated information regarding the occurrence of Dirofilariacirculating microfilariae in dogs from western and south-western Romania within the last decade, as well as data regarding the risk factors involved in the acquisition of Dirofilaria infections in Romania.

\section{Results}

The screening of the 1088 canine blood samples from the western and south-western areas of Romania-aiming to identify the Dirofilaria species-revealed an overall frequency rate of $21.42 \%(233 / 1088)$ for canine dirofilariosis (detailed in Table 1).

Table 1. Number and prevalence of canine Dirofilaria infections and co-infections in the studied counties from western and south-western Romania.

\begin{tabular}{|c|c|c|c|c|c|c|c|c|}
\hline CRT. NO. & COUNTIES & $\begin{array}{c}\text { NO. } \\
\text { SAMPLES }\end{array}$ & $\begin{array}{c}\text { NO. } \\
\text { POSITIVE }\end{array}$ & $\begin{array}{c}\text { PREVALENCE } \\
(\%)\end{array}$ & $\begin{array}{l}\text { D. immitis } \\
\text { (NO.) }\end{array}$ & $\begin{array}{l}\text { D. repens } \\
\text { (NO.) }\end{array}$ & $\begin{array}{l}\text { A. reconditum } \\
\text { (NO.) }\end{array}$ & $\begin{array}{c}\text { D. immitis + } \\
\text { D. repens } \\
\text { (NO.) }\end{array}$ \\
\hline 1 & Arad & 47 & 12 & 25.53 & 3 & 9 & 0 & 0 \\
\hline 2 & Bihor & 33 & 2 & 6.06 & 0 & 2 & 0 & 0 \\
\hline 3 & Caras Severin & 79 & 5 & 6.33 & 1 & 4 & 0 & 0 \\
\hline 4 & Dolj & 75 & 3 & 4.00 & 1 & 2 & 0 & 0 \\
\hline 5 & Gorj & 62 & 2 & 3.23 & 0 & 2 & 0 & 0 \\
\hline 6 & Hunedoara & 100 & 4 & 4.00 & 1 & 3 & 0 & 0 \\
\hline 7 & Mehedinti & 42 & 7 & 16.67 & 3 & 4 & 0 & 0 \\
\hline 8 & Olt & 52 & 5 & 9.62 & 1 & 4 & 0 & 0 \\
\hline 9 & Timis & 537 & 186 & 34.64 & 93 & 69 & 1 & 23 \\
\hline 10 & Valcea & 60 & 6 & 10.00 & 3 & 3 & 0 & 0 \\
\hline 11 & Bucuresti & 1 & 1 & - & 0 & 0 & 0 & 1 \\
\hline \multicolumn{2}{|c|}{ TOTAL } & 1088 & 233 & 21.42 & 106 & 102 & 1 & 24 \\
\hline
\end{tabular}

Legend: no-number.

The identified species in case of monoinfections were D. immitis, D. repens and Acanthocheilonema reconditum in 106 (9.74\%) samples, 102 (9.38\%) samples, and 1 (0.09\%) sample, respectively. Twenty-four $(2.21 \%)$ samples exhibited the simultaneous presence of D. immitis and D. repens.

The screening of samples coming from the various counties included in the study led to the identification of prevalence rates ranging from 3.23\% (2/62) in Gorj to $34.64 \%$ $(186 / 537)$ in Timiș (Table 1 and Figures 1-3). 


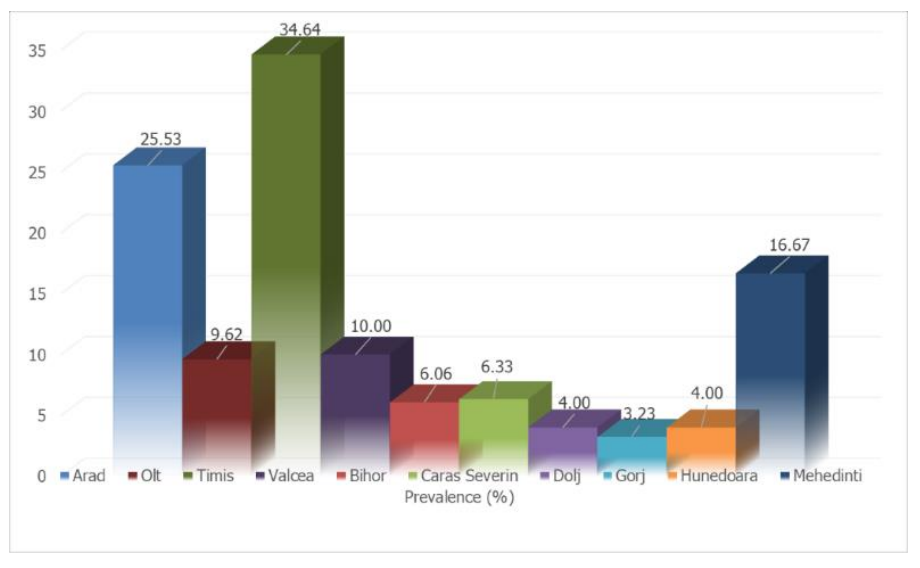

Figure 1. Percentage distribution of dogs positive for Dirofilaria-circulating microfilariae in western and south-western Romania.

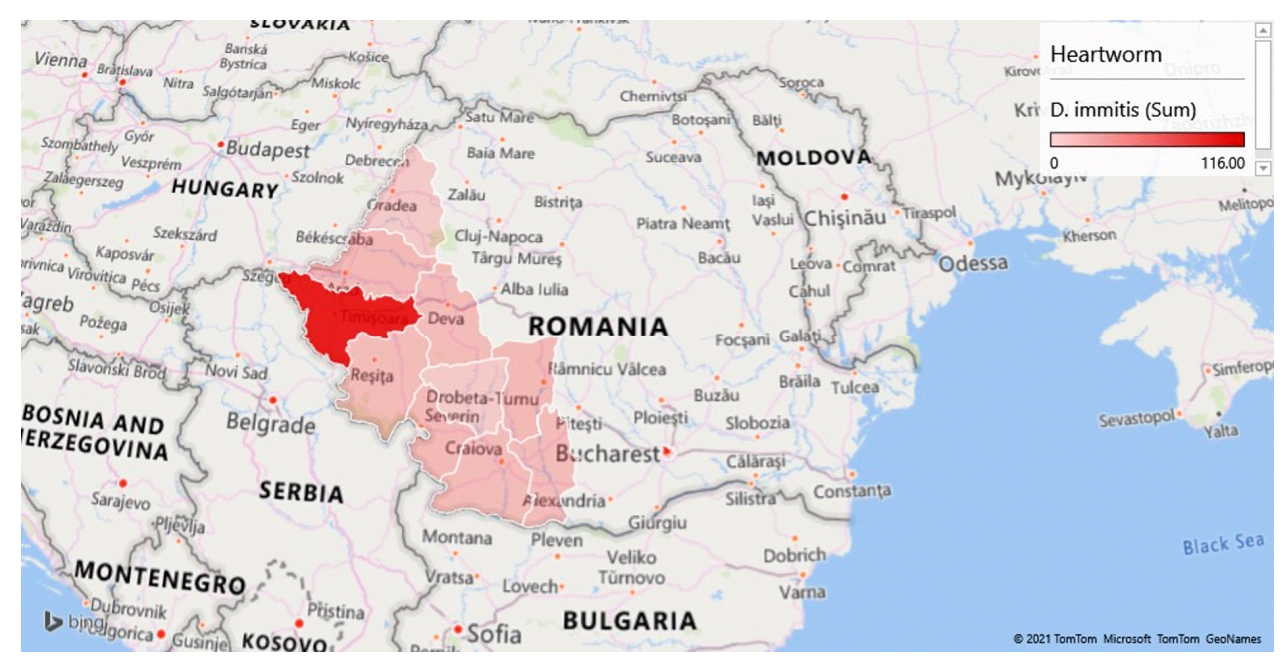

Figure 2. Geographical distribution of dogs positive for Dirofilaria immitis in western and southwestern Romania.

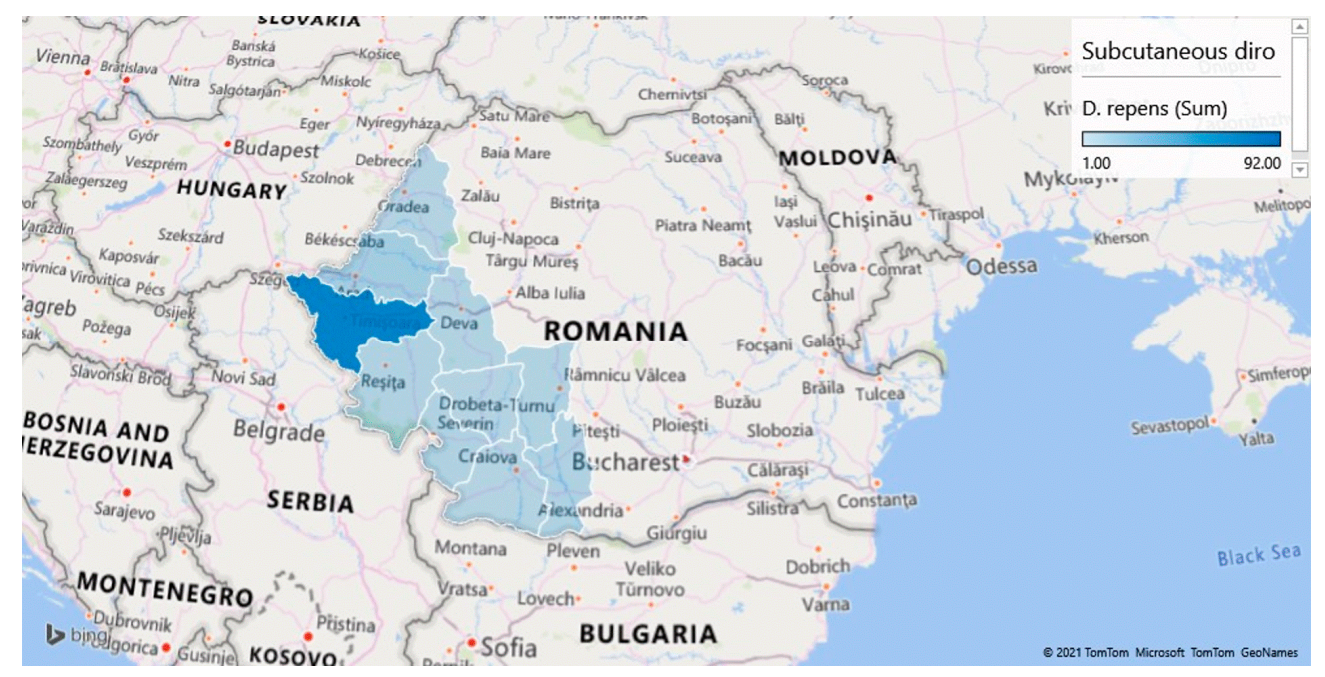

Figure 3. Geographical distribution of dogs testing positive for Dirofilaria repens in western and south-western Romania.

Dirofilaria repens was identified in 126 (11.58\%) samples following PCR examination (Figure 4). The assay was based on the amplification of a region of the $12 \mathrm{~S}$ rDNA gene. The 
$1.5 \%$ agarose gel migration products of the PCR multiplex highlighted bands of consistent width, with obvious bright bands at $500 \mathrm{bp}$ (genus diagnostic) and $327 \mathrm{bp}$ (Figure 5a,c). In contrast, the other 130 samples $(11.95 \%)$ generated migration bands characteristic for the D. immitis species at 500 and 204 pair bases (Figure $5 b, c$ ).

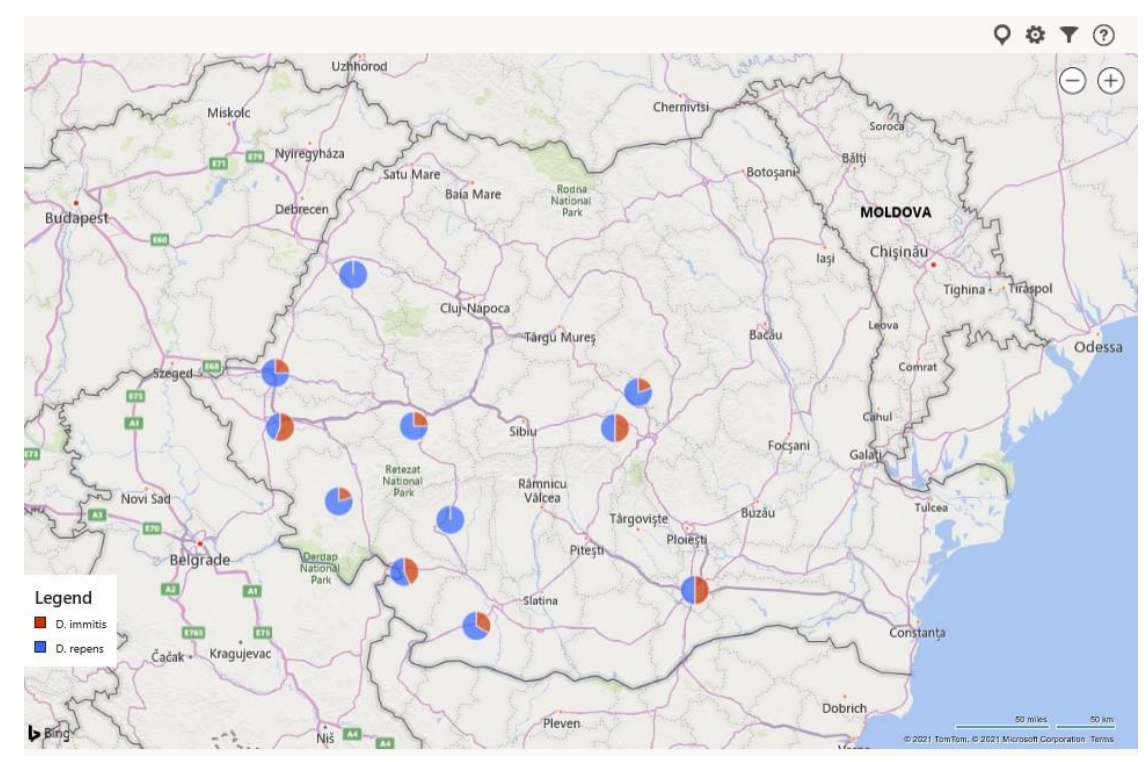

Figure 4. Geographical distribution of canine Dirofilaria-circulating microfilariae in western and south-western Romania.

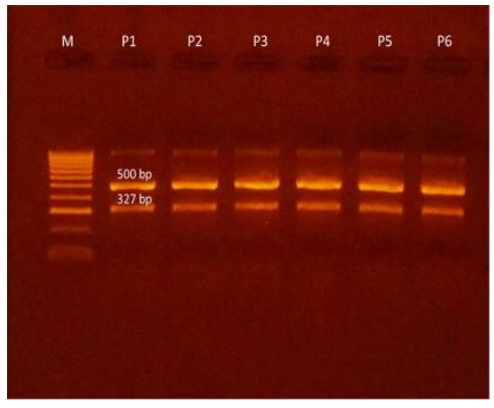

(a)

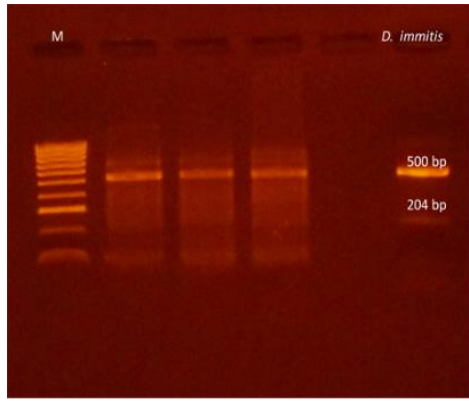

(b)

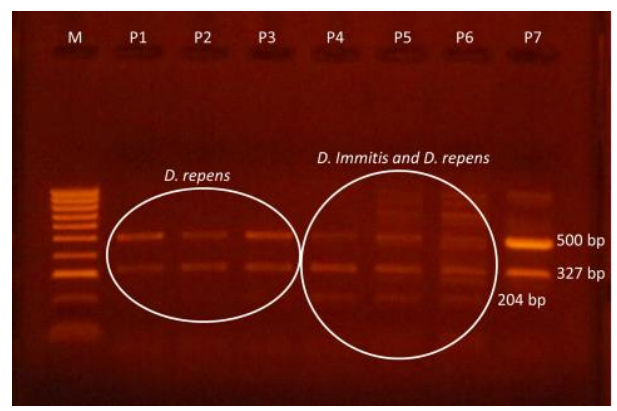

(c)

Figure 5. Migration bands of products resulted from multiplex-PCR during molecular diagnostic: (a) Dirofilaria repens ( $\mathrm{M}$-molecular weight-size marker; P1-6-positive samples); (b) Dirofilaria immitis (final column) $\mathrm{M}-$ molecular weight-size marker); (c) Dirofilaria repens and Dirofilaria immitis.

The comparative statistical analysis of the positive and negative cases revealed several age-related aspects (Tables 2 and 3). The risk of contracting Dirofilaria infections appears to increase with age, while animals below 1 year of age are not considered at risk. 
Table 2. Distribution of the dog population according to the studied risk factors.

\begin{tabular}{|c|c|c|c|}
\hline \multirow{2}{*}{ Epidemiological Data } & \multicolumn{2}{|c|}{ Positive } & \multirow{2}{*}{$\begin{array}{c}\text { Negative } \\
\text { NO. }\end{array}$} \\
\hline & NO. & $\%$ & \\
\hline \multicolumn{4}{|l|}{ Age } \\
\hline$\leq 1$ years $(n=123)$ & 13 & 10.57 & 110 \\
\hline 1 to $\leq 3$ years $(n=238)$ & 54 & 22.69 & 184 \\
\hline 3 to $\leq 6$ years $(n=214)$ & 71 & 33.18 & 143 \\
\hline$>6$ years $(n=202)$ & 65 & 32.18 & 137 \\
\hline $\mathrm{NA}^{*}(n=311)$ & 30 & 9.65 & 281 \\
\hline \multicolumn{4}{|l|}{ Gender } \\
\hline Female $(n=371)$ & 82 & 22.10 & 289 \\
\hline Male $(n=436)$ & 151 & 34.63 & 285 \\
\hline NA $(n=281)$ & 0 & 0.00 & 281 \\
\hline \multicolumn{4}{|l|}{ Breed } \\
\hline Purebreed $(n=276)$ & 88 & 31.88 & 188 \\
\hline Crossbreed $(n=531)$ & 145 & 27.31 & 386 \\
\hline NA $(n=281)$ & 0 & 0.00 & 281 \\
\hline \multicolumn{4}{|l|}{ Habitat } \\
\hline Urban $(n=727)$ & 126 & 17.33 & 601 \\
\hline Rural $(n=361)$ & 107 & 29.64 & 254 \\
\hline \multicolumn{4}{|l|}{ Owner/shelter } \\
\hline owner $(n=1028)$ & 173 & 16.83 & 855 \\
\hline shelter $(n=60)$ & 60 & 100.00 & 0 \\
\hline Total & 233 & $\begin{array}{c}21.42 \\
1088\end{array}$ & 855 \\
\hline
\end{tabular}

${ }^{*}$ NA-not available.

Table 3. The statistical analysis between positive and negative cases according to the studied risk factors.

\begin{tabular}{|c|c|c|c|}
\hline Epidemiological Risk Factors & Compared Groups & $p$-Value & $p$-Value Interpretation \\
\hline \multirow{5}{*}{ Age } & $\begin{array}{c}\leq 1 \text { year vs. } 1 \text { to } \leq 3 \\
\text { years }\end{array}$ & 0.0044 & $\begin{array}{l}\text { very statistically } \\
\text { significant }\end{array}$ \\
\hline & $\begin{array}{c}\leq 1 \text { year vs. } 3 \text { to } \leq 6 \\
\text { years }\end{array}$ & 0.0001 & $\begin{array}{l}\text { highly statistically } \\
\text { significant }\end{array}$ \\
\hline & $\leq 1$ year vs. $>6$ years & 0.0001 & $\begin{array}{l}\text { highly statistically } \\
\text { significant }\end{array}$ \\
\hline & 1 to $\leq 3$ years vs. 3 to $\leq 6$ & 0.0153 & statistically significant \\
\hline & $\begin{array}{c}1 \text { to } \leq 3 \text { years vs. }>6 \\
\text { years }\end{array}$ & 0.0311 & statistically significant \\
\hline Gender & female vs. male & 0.0001 & $\begin{array}{l}\text { highly statistically } \\
\text { significant }\end{array}$ \\
\hline Breed & purebred vs. crossbreed & 0.1903 & $\begin{array}{l}\text { not statistically } \\
\text { significant }\end{array}$ \\
\hline Habitat & urban vs. rural & 0.0001 & $\begin{array}{l}\text { highly statistically } \\
\text { significant }\end{array}$ \\
\hline Owner/shelter & owner vs. shelter & 0.0001 & $\begin{array}{l}\text { highly statistically } \\
\text { significant }\end{array}$ \\
\hline
\end{tabular}


The statistical difference between positive and negative cases was highly significant in terms of sex distribution. This applied to urban-rural distribution of cases as well as to the categories of dogs with owners and dogs from shelters.

There were no statistically significant differences between the positive and negative animals in terms of breed distribution.

\section{Discussion}

Several published studies and case reports mention the infection with Dirofilaria in Romania, revealing various prevalence rates among dogs [14-19], cats [20,21], or wild carnivores [22] from different areas. The present study, conducted under extensive spatial (almost a quarter of all counties (11/41)) and temporal conditions (over a 10 year period) brings updated and valuable information on this subject.

In Europe, infection with Dirofilaria spp. in dogs was identified in many countries including Austria [12], the Baltic countries [23], Bulgaria [24], the Czech Republic and Slovakia [25], France [26], Greece [6,27], Hungary [28], Italy [29-31], Serbia [32], and Spain [33], with minor differences among reports [13]. An up-to-date and accurate picture of Dirofilaria infections in central and northern European countries is provided by a study by Fuehrer et al., 2021, which states that, although the number of studies has increased in recent years, epizootiological knowledge is fragmented [34].

Outside Europe, dirofilariosis was detected in Thailand [35,36], French Guyana [37], Nepal [38], Iran [39], and the USA [8,40].

Anvari et al. (2020) [41] evaluated the global status of D. immitis infections in dogs, based on data available in literature $(8.78 \%$ in Romania, $10.45 \%$ in Europe, and $10.91 \%$ across the world). Genchi and Kramer (2020) [13] reported the prevalence rates of Dirofilaria immitis and D. repens in the Old World (between $3.6 \%$ and $42 \%$ in Romania).

Information regarding prophylactic therapy was not available for all studied dogs. It is widely acknowledged that the use of macrocyclic lactones leads to the disappearance of microfilaria from the blood stream, a fact which could influence the estimation process of the real prevalence rates. The use of immunochromatography or ELISA can compensate this underestimation though highlighting circulating antigens released by gravid Dirofilaria females. Underestimation may also occur if the animals are parasitized with only males, immature females, or if there are less than two gravid females which fail to produce detectable levels of antigens. The possibility for cross-reactions should also be taken into account, as well as the presence of antigen-antibody complexes that can be hidden following therapy based on macrocyclic lactones and can end up influencing the results of quick tests or ELISA assays. The modified Knott method is considered the gold standard diagnostic of Dirofilaria infections; moreover, there is an excellent correlation rate between this method, ELISA, and PCR tests [42-46].

On the other hand, animals infected with various helminths, such as Dipetalonema reconditum, Dirofilaria repens, Ancylostoma caninum, and Trichuris spp., have shown potential crossreactions. Furthermore, it has been suggested that the antigens of $A$. vasorum and $D$. immitis may share epitopes, which might lead to cross-reactions in antigen detection assays. Consequently, for epidemiological investigations in dogs with a suspected heart worm infection, the use of highly specific diagnostic techniques at the same time is suggested [47].

Statistical analysis showed that the risk factors were represented by age (above 1 year of age), sex, habitat, and whether the animals had an owner or came from the shelter. Breed and age factors (less than 1 year of age), were not considered risk factors.

When it comes to age as a risk factor in infections with Dirofilaria, there are several studies that support this aspect [15,48-52] and studies that did not reach any significant conclusions [53].

Regarding sex, males were considerably more affected (statistically) than females, a fact that is supported by Traversa et al., 2010 [54], but is contradicted by Ciucă et al., 2016 [15] and Muñoz et al., 2020 [53].

The origin of the animals (either urban or rural) and whether they had an owner or they came from the shelter have significantly influenced the prevalence of the infection 
with Dirofilaria. It can be considered that the animals from the rural environment are more exposed to the attack of vectors over longer periods of time, compared to animals from the urban environment. However, we cannot overlook the fact that owners from the urban environment tend to be more careful when it comes to their pets, compared to owners from the rural environment. The fact that animals from shelters do not benefit as much from deworming treatments, and the fact that dirofilariasis prevention has been faulty prior to their arrival in the shelter, has significantly influenced the possibility of infection with Dirofilaria spp.

A limitation in the molecular or parasitological diagnosis of canine heartworm disease is directly related to the fact that both methods target microfilariae. Occult infections with D. immitis can represent about $20-30 \%$ of all cases. In this situation, it is recommended to perform a method of detection/identification of microfilariae (Knott) as well as an antigen test $[6,10,37,43,55-57]$.

In our study, we can discuss the issue of underestimation regarding the prevalence of D. immitis, an aspect that cannot be discussed for D. repens.

\section{Materials and Methods}

The survey was conducted on a total of 1088 dogs from 11 counties in western and south-western Romania. The screened animals came from 73 localities (Figure 6) distributed at a countywide level as follows: Arad (5 localities), Bihor (5 localities), Timis, (27 localities), Caraș-Severin (9 localities), Hunedoara (5 localities), Mehedinți (2 localities), Dolj (4 localities), Gorj (5 localities), Olt (4 localities), Vâlcea (6 localities), and Bucharest (southern area of Romania), respectively.

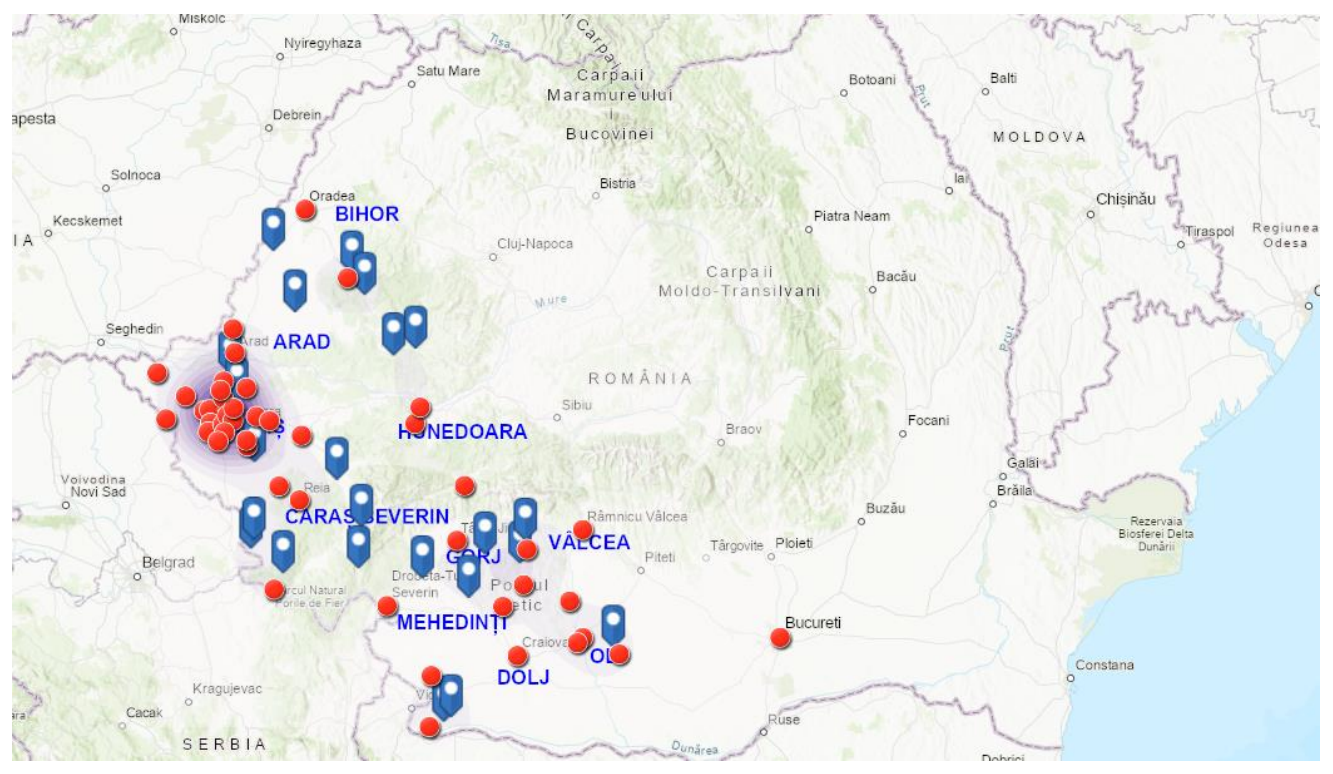

Figure 6. Map of Romania showing locations of sampling, where Dirofilaria positive (red dots) and negative (blue dots) dogs were identified.

The dogs included in the study, were randomly selected and they either came from shelters (60 dogs-5.5\%), were patients brought in for consultation at the University Veterinary Clinics of the Faculty of Veterinary Medicine from Timisoara (728 dogs-66.9\%) or from they were patients in private veterinary practices (300 dogs-27.6\%). The dogs were brought in for their annual vaccines, routine check-ups, or when presenting with various clinical signs.

The owners of dogs that were registered at the University Veterinary Clinics have signed an informed consent for the use of data, while the owners from private practices expressed their consent verbally. 
A blood sample was collected from each animal, in properly labelled $3 \mathrm{~mL}$ vacutainer tubes containing anticoagulant (EDTA), and all blood samples were sent to the parasitology laboratory from the University Veterinary Clinics for testing and species identification.

The modified Knott's technique [45] was performed on all samples in order to highlight the presence of microfilariae and for species differentiation. Subsequently, positive samples were confirmed through polymerase chain reaction (PCR), according to instructions by Gioia et al., 2010 [58].

The DNA was isolated from the blood samples using the PureLink ${ }^{\mathrm{TM}}$ Genomic DNA mini kit (Invitrogen ${ }^{\mathrm{TM}}$, Carlsbad, CA, USA), according to the manufacturer's instructions. Following extraction, the DNA samples were deposited at $-20{ }^{\circ} \mathrm{C}$ until further processing. Subsequently, the samples were subjected to the polymerase chain reaction procedure (PCR).

Thus, the basic technique consisted of the use of the PCR multiplex, based on an equimolar combination between a pair of general nematode primers (500 bp) - $12 \mathrm{SF}$ (5-GTTCCAGAATAATCGGCT A-3) and 12SRdeg (5-ATTGACGGA TG(AG)TTTGTACC3)-and a pair of specific primers for Dirofilaria immitis (204 bp) and Dirofilaria repens (327bp)-12SF2B (5-TTTTTACTTTTTTGGTAATG-3) and 12SR2 (5-AAAAGCAACACAAA TAA (CA)A-3) in $25 \mu \mathrm{L}$, respectively, targeting the $12 \mathrm{~S}$ rDNA gene. The amplification products were visualised in a $2.5 \%$ agarose gel, previously stained with ethidium bromide.

Statistical analysis was performed using Microsoft Excel GraphPad Software and Fischer's exact test, in order to establish the possible statistically significant differences among the recorded epidemiological data. The difference was considered significant when the $p$-value was $\leq 0.05$.

\section{Conclusions}

Canine dirofilariosis is continuously expanding in Romania, and the positivity rates for circulating microfilariae of $D$. immitis and $D$. repens are very similar $-11.95 \%$ and $11.58 \%$ respectively.

The results of the present investigation suggest possible zoonotic risks for humans living in the screened area. It has consequently become imperative to increase awareness among both veterinarians and physicians regarding the continuous spread of these zoonotic filariae.

Author Contributions: Conceptualization, M.S.I., M.I. and S.G.; methodology, M.S.I. and M.I.; software, M.S.I.; validation, G.D., S.M. and M.S.I.; formal analysis, M.S.I. and K.I.; investigation, S.G., I.L. and M.I.; resources, S.G., M.I., M.S.I. and K.I.; data curation, S.G., I.L. and M.I.; writing—original draft preparation, S.G. and M.S.I.; writing-review and editing, S.G., T.F. and K.I.; visualization, G.D.; supervision, G.D. and S.M.; All authors have read and agreed to the published version of the manuscript.

Funding: This research received no external funding. The APC was funded by own funds of Banat University of Agricultural Sciences and Veterinary Medicine, Timisoara and ESDA/SoIPa organization.

Institutional Review Board Statement: The study was conducted according to the guidelines of the Declaration of Helsinki, and the proper procedures of the University Veterinary Clinics of the Faculty of Veterinary Medicine Timișoara, approved by the Ethics Committee protocol number 34/1.12.2012 of the Romanian Veterinary College.

Informed Consent Statement: Not applicable.

Conflicts of Interest: The authors declare no conflict of interest. The funders had no role in the design of the study; in the collection, analyses, or interpretation of data; in the writing of the manuscript, or in the decision to publish the results. 


\section{References}

1. Gabrielli, S.; Mangano, V.; Furzi, F.; Oliva, A.; Vita, S.; Poscia, R.; Fazii, P.; Di Paolo, J.; Marocco, R.; Mastroianni, C.; et al. Molecular Identification of New Cases of Human Dirofilariosis (Dirofilaria repens) in Italy. Pathogens 2021, 10, 251. [CrossRef] [PubMed]

2. Otranto, D.; Dantas-Torres, F.; Brianti, E.; Traversa, D.; Petrić, D.; Genchi, C.; Capelli, G. Vector-borne helminths of dogs and humans in Europe. Parasites Vectors 2013, 6, 16. [CrossRef]

3. Dantas-Torres, F.; Otranto, D. Dirofilariosis in the Americas: A more virulent Dirofilaria immitis? Parasites Vectors 2013, 6, 288. [CrossRef] [PubMed]

4. Morelli, S.; Diakou, A.; Di Cesare, A.; Colombo, M.; Traversa, D. Canine and Feline Parasitology: Analogies, Differences, and Relevance for Human Health. Clin. Microbiol. Rev. 2021, 34, e0026620. [CrossRef]

5. Ciuca, L.; Vismarra, A.; Lebon, W.; Beugnet, F.; Morchon, R.; Rinaldi, L.; Cringoli, G.; Kramer, L.; Genchi, M. New insights into the biology, diagnosis and immune response to Dirofilaria repens in the canine host. Vet. Parasitol. 2020, 277, 100029. [CrossRef]

6. Diakou, A.; Kapantaidakis, E.; Tamvakis, A.; Giannakis, V.; Strus, N. Dirofilaria infections in dogs in different areas of Greece. Parasites Vectors 2016, 9, 508. [CrossRef]

7. Capelli, G.; Genchi, C.; Baneth, G.; Bourdeau, P.; Brianti, E.; Cardoso, L.; Danesi, P.; Fuehrer, H.-P.; Giannelli, A.; Ionică, A.M.; et al Recent advances on Dirofilaria repens in dogs and humans in Europe. Parasites Vectors 2018, 11, 663. [CrossRef]

8. Dantas-Torres, F.; Otranto, D. Overview on Dirofilaria immitis in the Americas, with notes on other filarial worms infecting dogs. Vet. Parasitol. 2020, 282, 109113. [CrossRef]

9. Brianti, E.; Panarese, R.; Napoli, E.; De Benedetto, G.; Gaglio, G.; Bezerra-Santos, M.A.; Mendoza-Roldan, J.A.; Otranto, D. Dirofilaria immitis infection in the Pelagie archipelago: The southernmost hyperendemic focus in Europe. Transbound. Emerg. Dis. 2021. [CrossRef] [PubMed]

10. American Heartworm Society. Current Canine Guidelines for the Prevention, Diagnosis, and Management of Heartworm (Dirofilaria immitis) Infection in Dogs. 2020. Available online: https://d3ft8sckhnqim2.cloudfront.net/images/pdf/2020_AHS_ Canine_Guidelines.pdf?1580934824 (accessed on 5 June 2021).

11. ESCCAP. GL5: Control of Vector-Borne Diseases in Dogs and Cats, 3rd ed.; ESCCAP: Worcestershire, UK, 2019. Available online: https: / / www.esccap.org/page/GL5+Control+of+VectorBorne+Diseases+in+Dogs+and+Cats/29/ (accessed on 5 June 2021).

12. Sonnberger, K.; Fuehrer, H.-P.; Sonnberger, B.; Leschnik, M. The Incidence of Dirofilaria immitis in Shelter Dogs and Mosquitoes in Austria. Pathogens 2021, 10, 550. [CrossRef]

13. Genchi, C.; Kramer, L.H. The prevalence of Dirofilaria immitis and D. repens in the Old World. Vet. Parasitol. 2019, $280,108995$. [CrossRef] [PubMed]

14. Mircean, V.; Dumitrache, M.O.; Györke, A.; Pantchev, N.; Jodies, R.; Mihalca, A.; Cozma, V. Seroprevalence and Geographic Distribution of Dirofilaria immitis and Tick-Borne Infections (Anaplasma phagocytophilum, Borrelia burgdorferi sensu lato, and Ehrlichia canis) in Dogs from Romania. Vector-Borne Zoonotic Dis. 2012, 12, 595-604. [CrossRef] [PubMed]

15. Ciucă, L.; Musella, V.; Miron, L.D.; Maurelli, M.P.; Cringoli, G.; Bosco, A.; Rinaldi, L. Geographic distribution of canine heartworm (Dirofilaria immitis) infection in stray dogs of eastern Romania. Geospat. Health 2016, 11, 499. [CrossRef] [PubMed]

16. Hamel, D.; Silaghi, C.; Lescai, D.; Pfister, K. Epidemiological aspects on vector-borne infections in stray and pet dogs from Romania and Hungary with focus on Babesia spp. Parasitol. Res. 2011, 110, 1537-1545. [CrossRef]

17. Ionică, A.M.; Matei, I.A.; Mircean, V.; Dumitrache, M.O.; D’Amico, G.; Győrke, A.; Pantchev, N.; Annoscia, G.; Albrechtová, K.; Otranto, D.; et al. Current surveys on the prevalence and distribution of Dirofilaria spp. and Acanthocheilonema reconditum infections in dogs in Romania. Parasitol. Res. 2014, 114, 975-982. [CrossRef] [PubMed]

18. Tomazatos, A.; Cadar, D.; Török, E.; Maranda, I.; Horváth, C.; Keresztes, L.; Spinu, M.; Jansen, S.; Jöst, H.; Schmidt-Chanasit, J.; et al. Circulation of Dirofilaria immitis and Dirofilaria repens in the Danube Delta Biosphere Reserve, Romania. Parasites Vectors 2018, 11, 392. [CrossRef]

19. Deak, G.; Ionică, A.M.; Szasz, I.; Taulescu, M.; Mihalca, A.D. A case of inguinal hernia associated with atypical Dirofilaria repens infection in a dog. Parasites Vectors 2021, 14, 125. [CrossRef] [PubMed]

20. Ciuca, L.; Roman, C.; Prisco, F.; Miron, L.; Acatrinei, D.; Paciello, O.; Maurelli, M.P.; Vismarra, A.; Cringoli, G.; Rinaldi, L. First report of Dirofilaria repens infection in a microfilaraemic cat from Romania. Vet. Parasitol. Reg. Stud. Rep. 2020, $22,100497$. [CrossRef]

21. Pană, D.; Rădulescu, A.; Mitrea, I.L.; Ionita, M. First report on clinical feline heartworm (Dirofilaria immitis) infection in Romania. Helminthologia 2020, 57, 49-56. [CrossRef] [PubMed]

22. Ionică, A.M.; Matei, I.A.; D’Amico, G.; Ababii, J.; Daskalaki, A.A.; Sándor, A.D.; Enache, D.V.; Gherman, C.M.; Mihalca, A.D. Filarioid infections in wild carnivores: A multispecies survey in Romania. Parasites Vectors 2017, 10, 332. [CrossRef] [PubMed]

23. Alsarraf, M.; Levytska, V.; Mierzejewska, E.J.; Poliukhovych, V.; Rodo, A.; Alsarraf, M.; Kavalevich, D.; Dwużnik-Szarek, D.; Behnke, J.M.; Bajer, A. Emerging risk of Dirofilaria spp. infection in Northeastern Europe: High prevalence of Dirofilaria repens in sled dog kennels from the Baltic countries. Sci. Rep. 2021, 11, 1068. [CrossRef] [PubMed]

24. Panayotova-Pencheva, M.; Šnábel, V.; Dakova, V.; Čabanová, V.; Cavallero, S.; Trifonova, A.; Mirchev, R.; Hurníková, Z.; Vasilková, Z.; Miterpáková, M. Dirofilaria immitis in Bulgaria: The first genetic baseline data and an overview of the current status. Helminthologia 2020, 57, 211-218. [CrossRef] 
25. Martina, M.; Zuzana, H.; Daniela, V.; Lenka, B. Different epidemiological pattern of canine dirofilariosis in two neighboring countries in Central Europe-the Czech Republic and Slovakia. Parasitol. Res. 2021, 120, 547-552. [CrossRef] [PubMed]

26. Laidoudi, Y.; Otranto, D.; Stolowy, N.; Amrane, S.; Manoj, R.S.; Polette, L.; Watier-Grillot, S.; Mediannikov, O.; Davoust, B.; L'Ollivier, C. Human and Animal Dirofilariasis in Southeast of France. Microorganisms 2021, 9, 1544. [CrossRef] [PubMed]

27. Diakou, A.; Di Cesare, A.; Morelli, S.; Colombo, M.; Halos, L.; Simonato, G.; Tamvakis, A.; Beugnet, F.; Paoletti, B.; Traversa, D. Endoparasites and vector-borne pathogens in dogs from Greek islands: Pathogen distribution and zoonotic implications. PLoS Negl. Trop. Dis. 2019, 13, e0007003. [CrossRef]

28. Farkas, R.; Mag, V.; Gyurkovszky, M.; Takács, N.; Vörös, K.; Solymosi, N. The current situation of canine dirofilariosis in Hungary. Parasitol. Res. 2019, 119, 129-135. [CrossRef]

29. Colombo, M.; Morelli, S.; Simonato, G.; Di Cesare, A.; Veronesi, F.; di Regalbono, A.F.; Grassi, L.; Russi, I.; Tiscar, P.; Morganti, G.; et al. Exposure to Major Vector-Borne Diseases in Dogs Subjected to Different Preventative Regimens in Endemic Areas of Italy. Pathogens 2021, 10, 507. [CrossRef]

30. Petruccelli, A.; Ferrara, G.; Iovane, G.; Schettini, R.; Ciarcia, R.; Caputo, V.; Pompameo, M.; Pagnini, U.; Montagnaro, S. Seroprevalence of Ehrlichia spp., Anaplasma spp., Borrelia burgdorferi sensu lato, and Dirofilaria immitis in Stray Dogs, from 2016 to 2019, in Southern Italy. Animals 2020, 11, 9. [CrossRef]

31. Morelli, S.; Gori, F.; Colombo, M.; Traversa, D.; Sarrocco, G.; Simonato, G.; Nespeca, C.; Di Cesare, A.; di Regalbono, A.F.; Veronesi, F.; et al. Simultaneous Exposure to Angiostrongylus vasorum and Vector-Borne Pathogens in Dogs from Italy. Pathogens 2021, 10, 1200. [CrossRef]

32. Savić, S.; Stosic, M.Z.; Marcic, D.; Hernández, I.; Potkonjak, A.; Otasevic, S.; Ruzic, M.; Morchón, R. Seroepidemiological Study of Canine and Human Dirofilariasis in the Endemic Region of Northern Serbia. Front. Vet. Sci. 2020, 7, 571. [CrossRef] [PubMed]

33. Montoya-Alonso, J.A.; Morchón, R.; Costa-Rodríguez, N.; Matos, J.I.; Falcón-Cordón, Y.; Carretón, E. Current Distribution of Selected Vector-Borne Diseases in Dogs in Spain. Front. Vet. Sci. 2020, 7, 564429. [CrossRef]

34. Fuehrer, H.-P.; Morelli, S.; Unterköfler, M.S.; Bajer, A.; Bakran-Lebl, K.; Dwużnik-Szarek, D.; Farkas, R.; Grandi, G.; Heddergott, M.; Jokelainen, P.; et al. Dirofilaria spp. and Angiostrongylus vasorum: Current Risk of Spreading in Central and Northern Europe. Pathogens 2021, 10, 1268. [CrossRef]

35. Satjawongvanit, H.; Phumee, A.; Tiawsirisup, S.; Sungpradit, S.; Brownell, N.; Siriyasatien, P.; Preativatanyou, K. Molecular Analysis of Canine Filaria and Its Wolbachia Endosymbionts in Domestic Dogs Collected from Two Animal University Hospitals in Bangkok Metropolitan Region, Thailand. Pathogens 2019, 8, 114. [CrossRef] [PubMed]

36. Loymek, S.; Phuakrod, A.; Zaelai, K.; Sripumkhai, W.; Vongjaroensanti, P.; Wongkamchai, S. Investigation on the Prevalence of Canine Microfilaremia in Thailand Using a Novel Microfluidic Device in Combination with Real-Time PCR. Vet. Sci. 2021, 8, 39. [CrossRef]

37. Laidoudi, Y.; Marié, J.-L.; Tahir, D.; Watier-Grillot, S.; Mediannikov, O.; Davoust, B. Detection of Canine Vector-Borne Filariasis and Their Wolbachia Endosymbionts in French Guiana. Microorganisms 2020, 8, 770. [CrossRef] [PubMed]

38. Rimal, S.; Adhikari, A.; Acharya, R.; Singh, D.K.; Joshi, N.P.; Shrestha, B.; Kaphle, K.; El-Dakhly, K.M.; Giannelli, A. Occurrence of Dirofilaria immitis in Stray Dogs from Nepal. Acta Parasitol. 2021, 1-7. [CrossRef]

39. Naderi, A.; Sharifi, I.; Aflatoonian, M.R.; Mostafavi, M.; Parizi, M.H.; Mashayekhi, J.; Mashayekhi, M.; Nikpour, S.; Bamorovat, M. Dirofilariosis caused by Dirofilaria immitis in the south of Kerman province, Iran. Microb. Pathog. 2021, 154, 104863. [CrossRef] [PubMed]

40. Little, S.; Braff, J.; Place, J.; Buch, J.; Dewage, B.G.; Knupp, A.; Beall, M. Canine infection with Dirofilaria immitis, Borrelia burgdorferi, Anaplasma spp., and Ehrlichia spp. in the United States, 2013-2019. Parasites Vectors 2021, 14, 10. [CrossRef]

41. Anvari, D.; Anvari, D.; Narouei, E.; Narouei, E.; Daryani, A.; Daryani, A.; Sarvi, S.; Sarvi, S.; Moosazadeh, M.; Moosazadeh, M.; et al. The global status of Dirofilaria immitis in dogs: A systematic review and meta-analysis based on published articles. Res. Vet. Sci. 2020, 131, 104-116. [CrossRef]

42. Panarese, R.; Iatta, R.; Mendoza-Roldan, J.A.; Szlosek, D.; Braff, J.; Liu, J.; Beugnet, F.; Dantas-Torres, F.; Beall, M.J.; Otranto, D. Comparison of Diagnostic Tools for the Detection of Dirofilaria immitis Infection in Dogs. Pathogens 2020, 9, 499. [CrossRef]

43. Trancoso, T.A.L.; Lima, N.D.C.; Barbosa, A.S.; Leles, D.; Fonseca, A.B.M.; Labarthe, N.V.; Bastos, O.M.P.; Uchôa, C.M.A. Detection of Dirofilaria immitis using microscopic, serological and molecular techniques among dogs in Cabo Frio, RJ, Brazil. Rev. Bras. Parasitol. Vet. 2020, 29, e017219. [CrossRef] [PubMed]

44. Wysmołek, M.E.; Klockiewicz, M.; Sobczak-Filipiak, M.; Długosz, E.; Wiśniewski, M. Case Studies of Severe Microfilaremia in Four Dogs Naturally Infected with Dirofilaria repens as the Primary Disease or a Disease Complicating Factor. Front. Vet. Sci. 2020, 7, 577466. [CrossRef]

45. Genchi, G.; Venco, L.; Genchi, M. Guideline for the laboratory diagnosis of canine and feline Dirofilaria infections. In Mappe Parassitologighe 8, Dirofilaria Immitis and Dirofilaria Repens in Dog and Cat and Human Infection; Genchi, C., Rinaldi, L., Cringoli, G., Eds.; Rolando Editore: Salamanca, Spain, 2007; pp. 137-145.

46. Genchi, M.; Ciuca, L.; Vismarra, A.; Ciccone, E.; Cringoli, G.; Kramer, L.; Rinaldi, L. Evaluation of alternative reagents on the performance of the modified Knott's test. Vet. Parasitol. 2021, 298, 109555. [CrossRef]

47. Schnyder, M.; Deplazes, P. Cross-reactions of sera from dogs infected with Angiostrongylus vasorum in commercially available Dirofilaria immitis test kits. Parasites Vectors 2012, 5, 258. [CrossRef] 
48. Köse, M.; Erdoğan, M. BMTW-Serological screening of canine heartworm (Dirofilaria immitis) infections in Turkey. Berl. Munch. Tierarztl. Wochenschr. 2012, 125, 503-508. [CrossRef]

49. Song, K.; Lee, S.; Hayasaki, M.; Shiramizu, K.; Kim, D.; Cho, K. Seroprevalence of canine dirofilariosis in South Korea. VeterParasitol. 2003, 114, 231-236. [CrossRef]

50. Lim, S.; Irwin, P.J.; Lee, S.; Oh, M.; Ahn, K.; Myung, B.; Shin, S. Comparison of selected canine vector-borne diseases between urban animal shelter and rural hunting dogs in Korea. Parasites Vectors 2010, 3, 32. [CrossRef]

51. Vieira, L.; Silvestre-Ferreira, A.; Fontes-Sousa, A.; Balreira, A.; Morchón, R.; Carretón, E.; Vilhena, H.; Simón, F.; Montoya-Alonso, J. Seroprevalence of heartworm (Dirofilaria immitis) in feline and canine hosts from central and northern Portugal. J. Helminthol. 2014, 89, 625-629. [CrossRef]

52. Kabuusu, R.M.; Stroup, D.F.; Pinckney, R.; Chriestmon, J.; Alexander, R.; Richards, C.; MacPherson, C. An analysis of time trends for canine heartworm disease in Grenada and its associated risk factors based on veterinary clinical pathology laboratory data base records between 2003 and 2015. Prev. Vet. Med. 2020, 179, 104989. [CrossRef] [PubMed]

53. Muñoz, A.A.F.; Martinez, A.R.; Pinilla, J.C. Prevalence of Dirofilaria immitis in shelter dogs in Bucaramanga metropolitan area, Colombia. Vet. Parasitol. Reg. Stud. Rep. 2020, 22, 100489. [CrossRef] [PubMed]

54. Traversa, D.; Di Cesare, A.; Conboy, G. Canine and feline cardiopulmonary parasitic nematodes in Europe: Emerging and underestimated. Parasites Vectors 2010, 3, 62. [CrossRef] [PubMed]

55. Laidoudi, Y.; Bedjaoui, S.; Medkour, H.; Latrofa, M.; Mekroud, A.; Bitam, I.; Davoust, B.; Otranto, D.; Mediannikov, O. Molecular Approach for the Diagnosis of Blood and Skin Canine Filarioids. Microorganisms 2020, 8, 1671. [CrossRef]

56. Yaman, M.; Guzel, M.; Koltas, I.; Demirkazik, M.; Aktas, H. Prevalence of Dirofilaria immitis in dogs from Hatay province, Turkey. J. Helminthol. 2009, 83, 255-260. [CrossRef] [PubMed]

57. Vieira, A.L.; Vieira, M.J.; Oliveira, J.; Simões, A.R.; Diez-Baños, P.; Gestal, J. Prevalence of canine heartworm (Dirofilaria immitis) disease in dogs of central Portugal. Parasite 2014, 21, 5. [CrossRef] [PubMed]

58. Gioia, G.; Lecová, L.; Genchi, M.; Ferri, E.; Genchi, C.; Mortarino, M. Highly sensitive multiplex PCR for simultaneous detection and discrimination of Dirofilaria immitis and Dirofilaria repens in canine peripheral blood. Vet. Parasitol. 2010, 172, 160-163. [CrossRef] 